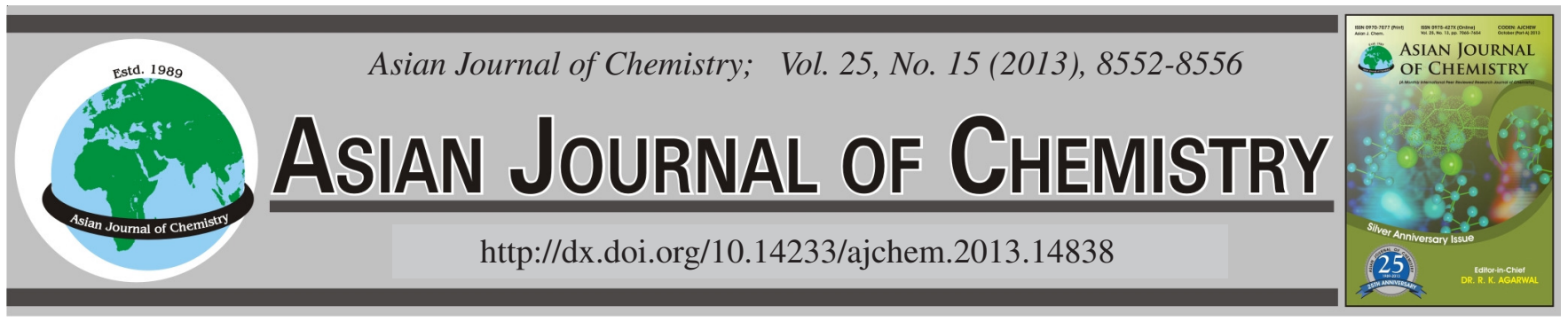

\title{
Evaluation of Heavy Metals in Tissue of Shellfish from Can Gio Coastline in Ho Chi Minh City, Vietnam
}

\author{
Nguyen Thi Kim Phuong ${ }^{1, *}$ and Nguyen Cuu KhoA ${ }^{2}$
}

${ }^{1}$ Institute of Chemical Technology, Vietnam Academy of Science and Technology, 01 Mac Dinh Chi, District 1, Ho Chi Minh City, Vietnam ${ }^{2}$ Institute of Applied Materials Science, Vietnam Academy of Science and Technology, 01 Mac Dinh Chi, District 1, Ho Chi Minh City, Vietnam

*Corresponding author: Fax: +84 8 38293889; Tel: +84 909 792142; E-mail: nguyenthikimp@yahoo.ca

\begin{abstract}
This study was undertaken to determine levels of contamination of toxic metals consumed shellfish products from Can Gio coastline located in southeast of Ho Chi Minh City, Vietnam. Concentrations of $\mathrm{As}, \mathrm{Cd}, \mathrm{Pb}, \mathrm{Cr}$ and $\mathrm{Mn}$ were determined in edible tissues of Mud Clam (Geloina coaxans), Clam (Meretrix lyrata), Subcrenata (Anadara subcrenata), Blood cockle (Anadara granosa), Asian green mussel (Perna viridis), White leg shrimp (Litopenaeus vannamei), Mud Crab (Scylla serrata) and Periwinkle (Litorina littorea). Sampling was carried out from March to April in 2012. Metal analysis was performed by atomic absorption spectrometry. Concentrations of As, Cd, $\mathrm{Pb}, \mathrm{Cr}$ and $\mathrm{Mn}$ in tissue ranged from Nd-0.67, 0.04-0.64, 0.10-2.51, 0.26-0.47 and 0.75-67.41 $\mu \mathrm{g} \mathrm{g}^{-1}$, respectively. The concentrations of heavy metals in all samples were lower than the permitted level set by ministry of health vietnam (MHV) and food and drug agent (FDA) except $\mathrm{Pb}$ in Scylla serrata. Therefore, the consumption of shellfish from Can Gio coastline might not pose a risk of metal toxicity. However, monitoring of the levels of $\mathrm{As}, \mathrm{Cd}, \mathrm{Pb}, \mathrm{Cr}$ and $\mathrm{Mn}$ in water and shellfish should be carried out routinely so that appropriate prevention of contamination from these toxic metals can be implemented.
\end{abstract}

Key Words: Shellfish, Arsenic, Cadmium, Lead, Chromium, Manganese.

\section{INTRODUCTION}

Environmental pollution represents a major problem in both developed and developing countries. Vietnam is one of the countries, which suffer from high biosphere pollution (air, soil and water). The main source of heavy metal pollution comes from discharge of untreated effluents from metal-related industries, such as electroplating, manufacturing of batteries and petrochemical industries.

Can Gio located in the southeast of Ho Chi Minh City, position at $106^{\circ} 46^{\prime} 12^{\prime \prime}$ to $107^{\circ} 00^{\prime} 50^{\prime \prime}$ East Longitude and from $10^{\circ} 22^{\prime} 14^{\prime \prime}$ to $10^{\circ} 40^{\prime} 00^{\prime \prime}$ north latitude Vietnam. With over 20 $\mathrm{km}$ of coastline running the southwest-northeast feed in many kinds of seafood such as: clams, shrimp, scallops, oysters, fish. Marine brings huge resources, so, in the economic structure of the district, the fishery has always been viewed as a key economic sector, is one of the driving forces of socio-economic development. However, Can Gio coastline receives many big major estuaries of the rivers such as Tau, Cai Mep, Go Gia, Thi Vai, Soai Rap, Dong Tranh. Most of these big rivers flow through the industrial area Saigon- Dong Nai capable of heavy metal pollution at highest concentration.
The increasing using of heavy metals in industry has led to serious environmental pollution and ecological damage. Heavy metals accumulate in the aquatic environments and then go to fish and shellfish products ${ }^{1}$. Heavy metals are of particular concern due to their toxicity and ability to be bioaccumulated in aquatic ecosystems as well as persistence in the natural environment ${ }^{2}$.

Arsenic, cadmium, lead, chromium and manganese are widely dispersed in the environment. They have no beneficial effects in humans and there is no known homeostasis mechanism for them ${ }^{3}$. It is well-known that long term exposure to As, $\mathrm{Cd}, \mathrm{Pb}, \mathrm{Cr}$ even at low levels can cause adverse effects to human health. For most people, the main route of exposure to these toxic elements is through the diet, unless some individuals are primarily exposed to these contaminants in the workplace ${ }^{4}$. Consequently, information about level of these contaminants in food is very important to assess risks to human health. Among the different metals analyzed, $\mathrm{As}, \mathrm{Cd}, \mathrm{Pb}$ and $\mathrm{Cr}$ are classified as chemical hazards and maximum residual levels have been prescribed for humans ${ }^{5,6}$.

Shellfish and fish have been considered good indicators for heavy metal contamination in aquatic systems because they 
occupy different trophic levels with different sizes and ages ${ }^{7}$. Meanwhile, shellfish and fish are widely consumed in many parts of the world by humans and polluted these products may endanger human health.

Therefore, this study is important to determine the level of $\mathrm{As}, \mathrm{Cd}, \mathrm{Pb}, \mathrm{Cr}$ and $\mathrm{Mn}$ in commonly consumed shellfish caught along the Can Gio coastline in Ho Chi Minh City, Vietnam. And then to compare the results obtained with the standard level of food issued by the MHV and FDA guidelines. Furthermore, data of this study could also be used to economically protect local and export market of the shellfish industries in Vietnam. In addition, it also gives important information on the safety aspect of local shellfish as consumer nowadays is aware on the beneficial intake of shellfish particularly for its high level of essential fatty acids.

\section{EXPERIMENTAL}

All reagents used were of analytical grade except pure $65 \%$ $\mathrm{HNO}_{3}$. Deionized water (18MÙ.cm) was used for the preparation of reagents and standards. Commercial standard solutions (1000 mg/L) of As, Cd, Pb, Cr and Mn were used (Merck). The working standard solutions were freshly prepared by diluting an appropriate aliquot of the standard stock solutions. All glassware was treated with $20 \%$ (v/v) $\mathrm{HNO}_{3}$ for $24 \mathrm{~h}$ and then rinsed three times with deionizer water before use.

Sample collection: Eight kinds of shellfish which are the most commonly consumed by the habitant of Ho Chi Minh city. Fresh shellfish were collected and randomly bought during March to April, 2012 from the local markets in Can Gio District. Table-1 shows the name, number of samples to be tested.

Sample preparation: As soon as arrival in the laboratory, shellfish samples were removed inedible parts, washed and frozen. All samples were kept at $-75^{\circ} \mathrm{C}$ without any prior treatment. Before analysis, composite sample of each species was prepared by mixing and grinding homogenously. All composite samples were packed into polyethylene covered cup, stored in freezer at $-20^{\circ} \mathrm{C}$ and analyzed within a week. Before digestion process, samples were dried for $72 \mathrm{~h}$ at $60-70{ }^{\circ} \mathrm{C}$ using air oven and grinded using mortar.

Analysis of Shellfish sample for heavy metals: The samples were digested in a MARS 5 microwave (CEM corp., USA) equipped with teflon closed vessels. Two gram dry shellfish sample was weighed out in the reaction vessel. Ten milliliter of $65 \% \mathrm{HNO}_{3}$ was then added to each vessel; three milliliter $\mathrm{HCl}$ are then added. The vessel was allowed to react for approximately 1 min prior to sealing and then be placed in the microwave. Heated the vessel to $165^{\circ} \mathrm{C}$ over 5 min and then held at $165^{\circ} \mathrm{C}$ for $10 \mathrm{~min}$. After digestion, the sample was allowed to cool. Then, elute was added with $25 \mathrm{~mL}$ deionizer water (sample solution). The quantification of $\mathrm{As}, \mathrm{Pb}, \mathrm{Cd}$ was performed with graphite furnace atomic absorption spectrophotometry (GF-AAS); Cr, Mn was performed with flame atomic absorption spectrophotometry (F-AAS) (AA6300, Shimadzu).

Determination of recovery: The digestion method and the atomic absorption spectrophotometry (AAS) analysis were validated by preparation of a multi-element standard solution containing $1000 \mathrm{mg} / \mathrm{L}$ of each metal. Prior to digestion method, samples were spiked with $5 \mathrm{ppm}$ of $\mathrm{As}, \mathrm{Cd}, \mathrm{Pb}, \mathrm{Cr}$ and $\mathrm{Mn}$. All spiked samples were prepared in duplicates and taken through the entire digestion procedures similarly to the analyses of the sample. They were used to check for recoveries after the analyses.

Statistical analysis: Statistical analysis of data was carried out using SPSS 16.0 version. A one-way analysis of variance (ANOVA) was performed, followed by LSD post hoc comparisons for the source of statistically significant difference. Differences in mean values were accepted as being statistically significant if $p<0.05$.

\section{RESULTS AND DISCUSSION}

The methods were also checked for suitability using the wet shellfish samples spiked with 5 ppm of $\mathrm{As}, \mathrm{Cd}, \mathrm{Pb}, \mathrm{Cr}$ and $\mathrm{Mn}$. The mean recoveries obtained were $104.8 \%$ for As, $100.8 \%$ for $\mathrm{Cd}, 94.0 \%$ for $\mathrm{Pb}, 97.4 \%$ for $\mathrm{Cr}$ and $95.0 \%$ for $\mathrm{Mn}$ (Table-2) and the relative standard deviation (RSD) values were less than $15 \%$. The results obtained the spiked shellfish samples indicated that the methods used were suitable for the determination of $\mathrm{As}, \mathrm{Cd}, \mathrm{Pb}, \mathrm{Cr}$ and $\mathrm{Mn}$ in the samples investigated.

The observed metal concentrations in muscle tissues of different shellfish species collected from Can Gio district during March to April 2012 were presented in Table-3.

In this study, the metal concentrations in muscle tissues varied significantly among the eight species. Concentrations of heavy metals in shellfish were compared with the permitted level recommended by the MHV and FDA. The differences in concentration in each sample were depending on species, sex biological cycle and the portion of sample being analyzed ${ }^{8}$. Furthermore, ecological factors such as season, place of

TABLE-1

COMMON AND SCIENTIFIC NAME, NUMBER OF SAMPLES AND NUMBER OF INDIVIDUALS FOR EACH SAMPLE

\begin{tabular}{|c|c|c|c|}
\hline Scientific name & Common name & No. of analysis sample & No. of individual per one sample \\
\hline \multicolumn{4}{|c|}{ Bivalves } \\
\hline Geloina coaxans & Mud clam & 8 & 40 \\
\hline Meretrix lyrata & Clam & 9 & 50 \\
\hline Anadara subcrenata & Subcrenata & 6 & 40 \\
\hline Anadara granosa & Blood cockle & 7 & 40 \\
\hline Perna viridis & Asian green mussel & 9 & 30 \\
\hline \multicolumn{4}{|c|}{ Crustaceans } \\
\hline Litopenaeus vannamei & White leg shrimp & 5 & 25 \\
\hline Scylla serrata & Mud crab & 5 & 7 \\
\hline \multicolumn{4}{|c|}{ Gastropoda } \\
\hline Litorina littorea & Periwinkle & 7 & 40 \\
\hline
\end{tabular}


TABLE-2

RECOVERIES FOR SPIKED SHELLFISH SAMPLES USED IN ANALYSIS

\begin{tabular}{|c|c|c|c|c|c|}
\hline & As & $\mathrm{Cd}$ & $\mathrm{Pb}$ & $\mathrm{Cr}$ & $\mathrm{Mn}$ \\
\hline Mean recovery $(\%)$ & 104.8 & 100.8 & 94.0 & 97.4 & 95.0 \\
\hline Relative standard deviation (\%) & 13.47 & 9.3 & 9 & 4.8 & 12.31 \\
\hline No of analyses (n) & 5 & 6 & 7 & 7 & 8 \\
\hline LOD (ppb) & 3 & 2 & 1.2 & 50 & $10^{2}$ \\
\hline LOQ (ppb) & 10.0 & 6.7 & 4.0 & $1.7 \times 10^{2}$ & $3.3 \times 10^{2}$ \\
\hline
\end{tabular}

TABLE-3

CONCENTRATIONS OF As, $\mathrm{Cd}, \mathrm{Pb}, \mathrm{Cu}, \mathrm{Zn}$ AND Mn IN $\mu \mathrm{g} \mathrm{g}{ }^{-1}$ WET WEIGHT (MEAN \pm STANDARD DEVIATION)

\begin{tabular}{|c|c|c|c|c|c|}
\hline Sample & As & $\mathrm{Cd}$ & $\mathrm{Pb}$ & $\mathrm{Cr}$ & $\mathrm{Mn}$ \\
\hline Geloina coaxans & $0.080 \pm 0.011$ & $0.285 \pm 0.010$ & $0.153 \pm 0.073$ & $0.279 \pm 0.043$ & $1.668 \pm 0.036$ \\
\hline Meretrix lyrata & $0.045 \pm 0.010$ & $0.087 \pm 0.009$ & $0.208 \pm 0.033$ & - & $5.052 \pm 1.199$ \\
\hline Anadara subcrenata & $0.039 \pm 0.012$ & $0.635 \pm 0.018$ & $0.100 \pm 0.098$ & $0.330 \pm 0.015$ & $3.008 \pm 0.089$ \\
\hline Anadara granosa & $0.674 \pm 0.077$ & $0.410 \pm 0.025$ & $0.224 \pm 0.219$ & $0.280 \pm 0.050$ & $3.466 \pm 0.213$ \\
\hline Perna viridis & $0.191 \pm 0.047$ & $0.038 \pm 0.004$ & $0.207 \pm 0.037$ & $0.467 \pm 0.042$ & $67.412 \pm 1.458$ \\
\hline Litopenaeus vannamei & ND & $0.036 \pm 0.010$ & $0.276 \pm 0.034$ & - & $0.951 \pm 0.033$ \\
\hline Scylla serrata & ND & $0.279 \pm 0.036$ & $2.510 \pm 0.310$ & - & $13.015 \pm 0.989$ \\
\hline Litorina littorea & ND & $0.079 \pm 0.010$ & $0.182 \pm 0.135$ & $0.258 \pm 0.055$ & $3.398 \pm 0.085$ \\
\hline MHV $\mu \mathrm{g} \mathrm{g}^{-1}$ & $1-2$ & $0.5-1$ & $0.5-1.5$ & - & - \\
\hline FDA $\mu \mathrm{g} \mathrm{g}^{-1}$ & $76-86$ & $3-4$ & $1.5-1.7$ & $12-13$ & - \\
\hline
\end{tabular}

Nd: below detection limit; MHV: Ministry of health of Vietnam.

development, nutrient availability, temperature and salinity of the water may also contribute to the inconsistency of metals concentration in shellfish tissue $\mathrm{e}^{8,9}$. Moreover, some marine organisms have the ability to concentrate heavy metals in their tissue in several orders of magnitude higher than those in water and sediment ${ }^{10}$.

The highest concentration of As accumulation was observed in Anadara granosa $\left(0.67 \mu \mathrm{g} \mathrm{g}^{-1}\right)$, followed by Perna viridis $\left(0.19 \mu \mathrm{g} \mathrm{g}^{-1}\right)$, Geloina coaxans $\left(0.08 \mu \mathrm{g} \mathrm{g}^{-1}\right)$, Meretrix lyrata $\left(0.05 \mu \mathrm{g} \mathrm{g}^{-1}\right)$, Anadara subcrenata $\left(0.04 \mu \mathrm{g} \mathrm{g}^{-1}\right)$. However, three of eight species of shellfish analyzed for total As content: Litopenaeus vannamei, Scylla serrata and Litorina littorea had mean values below the detection limits for the method used. The significant different concentration of As in bivalve species it could be because the habitat of bivalve species that are living at the bottom of sea, nearly to the sediment where various kinds of hazardous and toxic substances are accumulated ${ }^{11}$. Furthermore, the environmental conditions and seasonal fluctuations of lipids may influence the heavy metals to accumulate ${ }^{12}$. All shellfish tissue As concentrations from Can Gio coastline are lower than concentrations reported by Alina et al..$^{12}$, Mat ${ }^{13}$, Suhaimi et al. ${ }^{14}$, Pimonwan et al ${ }^{15}$. Concentration of As in all of samples were well below safe limits set by the MHV and FDA. Inorganic As is most toxic and considered as a group A human carcinogenic, chronic exposure to inorganic arsenic may give rise to several health effects, including to the gastrointestinal tract, respiratory tract, skin disorder, liver, lung, kidney, cardiovascular system and the nervous system ${ }^{16,17}$.

Whereas, Cd observations in bivalves group in this study ranged from $0.04 \mu \mathrm{g} \mathrm{g}^{-1}$ (Perna viridis) to $0.64 \mu \mathrm{g} \mathrm{g}^{-1}$ (Anadara subcrenata). The concentration of $\mathrm{Cd}$ in crustacean group was $0.04-0.28 \mu \mathrm{g} \mathrm{g}^{-1}$ with the highest in Scylla serrata. Cd concentrations in shellfish from Can Gio coastal were similar quantity to those from Singapore ${ }^{14}$ and lower than those reported by Alina et al. ${ }^{12}$, Pimonwan et al. ${ }^{15}$. Cadmium contents in shellfish tissue from Can Gio coastal are within the safe limits prescribed by the MHV and FDA. Cadmium is known to accumulate in the human kidney from 20-30 years and at high doses, is also known to produce health effects on the respiratory system, poor reproductive capacity, hypertension, tumors and hepatic dysfunction $^{18,19}$. Cadmium can be accumulated with metallothioneins ${ }^{13}$ and uptake of 1.5-9.0 $\mathrm{mg} \mathrm{day}^{-1}$ is lethal to humans $\mathrm{s}^{20}$.

Lead was detected in all the samples and the concentrations of $\mathrm{Pb}$ were found to be $0.10-2.51 \mu \mathrm{g} \mathrm{g}^{-1}$. The highest concentrations of $\mathrm{Pb}$ were found in Scylla serrata muscle (2.51 $\left.\mu \mathrm{g} \mathrm{g}^{-1}\right) . \mathrm{Pb}$ in muscle of bivalve group ranged from $0.10-0.224$ $\mu \mathrm{g} \mathrm{g}^{-1}$. In general, $\mathrm{Pb}$ values obtained from this study were lower than those reported earlier by Alina et al. ${ }^{12}$, Mat ${ }^{13}$, Le Thi Mui ${ }^{21}$ but similar concentration in comparison to those reported by Suhaimi et al. ${ }^{14}$. Pb concentration in most of shellfish tissue from Can Gio coastal was well below the acceptable limits proposed by the MHV amd FDA except Scylla serrata tissue. Some of the known symptoms of $\mathrm{Pb}$ poisoning are headache, irritability, abnormal pain, renal failure, liver damage and various symptoms related to nervous system in human ${ }^{22,23}$. The maximum permissible doses for an adult are $3 \mathrm{mg} \mathrm{Pb}$ per week, but the recommended doses are only one-fifth of those quantities $^{24}$.

Chromium results obtained for different tissues are summarized in Table-3. The highest concentration of $\mathrm{Cr}(0.47$ $\mu \mathrm{g} \mathrm{g}^{-1}$ ) was detected in Perna viridis. Chromium contents in shellfish from Can Gio coastal were well below the acceptable limits of $12-13 \mu \mathrm{g} \mathrm{g}^{-1}$ prescribed by the FDA. There is no standard limited concentration for Cr in Vietnam. The World Health Organization (WHO) has proposed that $\mathrm{Cr}(\mathrm{VI})$ is a human carcinogen. Several studies have shown that $\mathrm{Cr}(\mathrm{VI})$ compounds can increase in risk of lung cancer ${ }^{25}$.

Manganese is the element found in the highest concentration of the edible tissue. Although this element is low toxicity, it has a considerable biological significance and seems to accumulate in certain aquatic species ${ }^{26,27}$. The highest mean concentration of Mn was recorded in the Perna viridis (67.41 $\left.\mu \mathrm{g} \mathrm{g}^{-1}\right)$. The lowest concentration of Mn was recorded in the Litopenaeus vannamei $\left(0.75 \mu \mathrm{g} \mathrm{g}^{-1}\right)$. Mean Mn concentration 


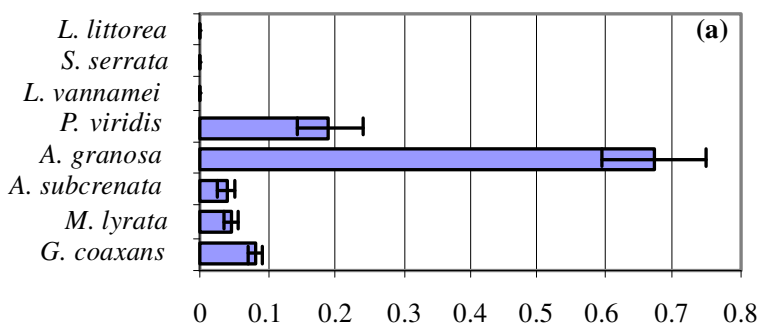

As in wet weight $(\mu \mathrm{g} / \mathrm{g})$
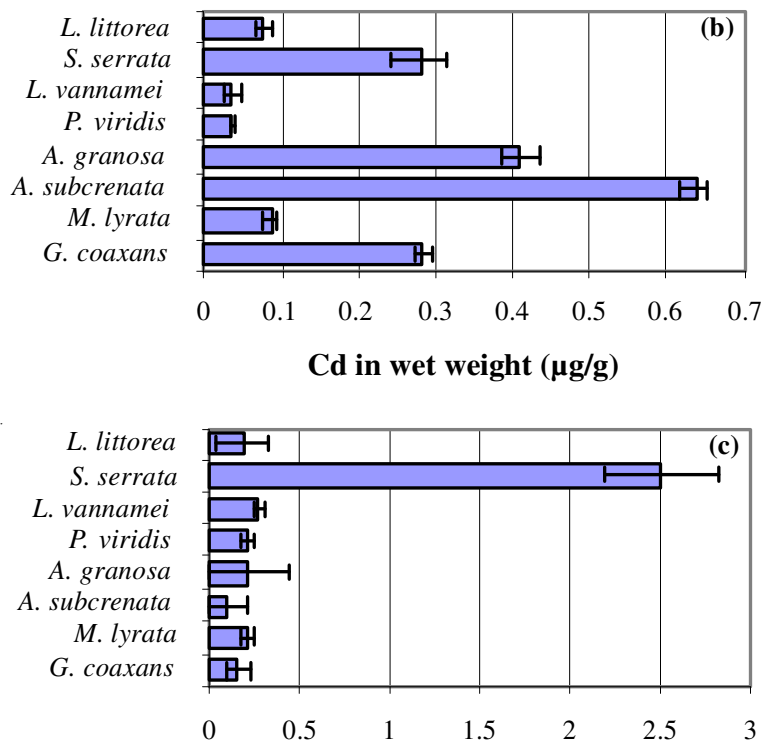

$\mathrm{Pb}$ in wet weight $(\mu \mathrm{g} / \mathrm{g})$
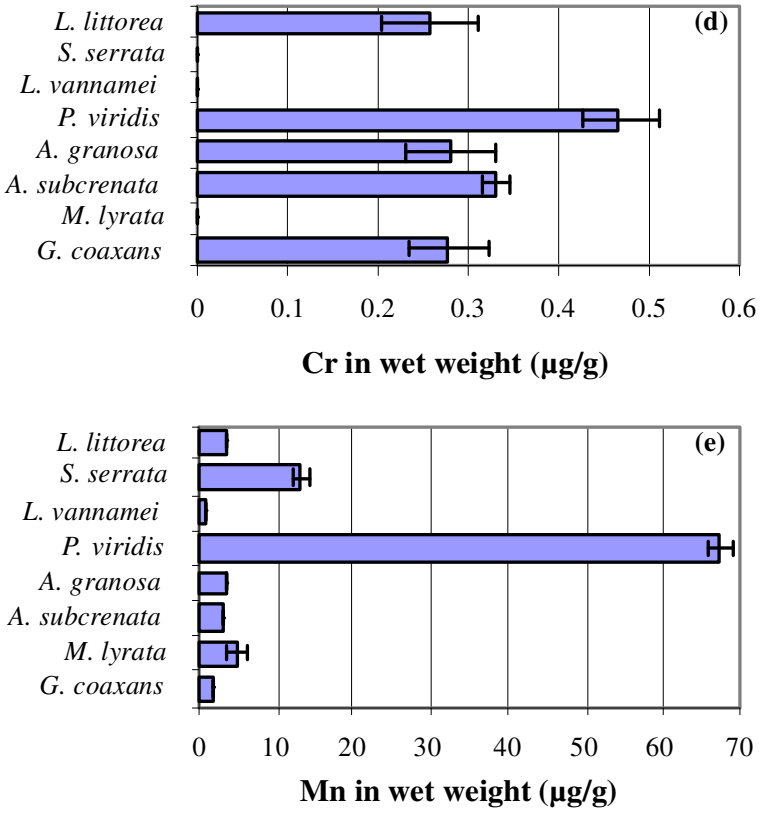

Fig. 1. Concentrations of $\mathrm{As}, \mathrm{Cd}, \mathrm{Pb}, \mathrm{Cr}$ and $\mathrm{Mn}(\mu \mathrm{g} / \mathrm{g}$ of wet weight) in shellfish from Can Gio district in Ho Chi Minh City, Vietnam: (a) As; (b) $\mathrm{Cd}$; (c) $\mathrm{Pb}$; (d) $\mathrm{Cr}$ and (e) $\mathrm{Mn}$

in other species was found $1.67 \mu \mathrm{g} \mathrm{g}^{-1}$ for Geloina coaxans, $5.05 \mu \mathrm{g} \mathrm{g}^{-1}$ for Meretrix lyrata, $3.01 \mu \mathrm{g} \mathrm{g}^{-1}$ for Anadara subcrenata, $3.47 \mu \mathrm{g} \mathrm{g}^{-1}$ for Anadara granosa, $13.02 \mu \mathrm{g} \mathrm{g}{ }^{-1}$ for Scylla serata and $3.40 \mu \mathrm{g} \mathrm{g}^{-1}$ for Litorina littorea. Because, $\mathrm{Mn}$ is an essential nutrient, a certain amount must be ingested on a regular basis to maintain health. Although the precise requirement has not been determined, but 2.5-5.0 $\mathrm{mg}$ per day (mg/day) has been estimated to constitute an adequate and safe intake ${ }^{28}$.

Heavy metals, such as $\mathrm{As}, \mathrm{Pb}, \mathrm{Cd}$ and $\mathrm{Cr}$ have no biological role, at higher concentrations; they can become toxic for living organisms because of their accumulation properties. Therefore, at the top of the trophic chain, human beings are especially sensitive to these contaminants due to bioaccumulation.

From Table-3, the levels of As, Cd, Cr, Mn in all samples from Can Gio coastline were lower than the permitted level set by MHV and FDA except $\mathrm{Pb}$ in Scylla serrata, thus making the studied shellfish are safe in terms of these heavy metals concentration. Although there are no high levels of heavy metals in shellfish from Can Gio coastal but a potential danger may occur in the future, depending on agricultural and industrial development in this region. Fig. 1 presented the concentration of $\mathrm{As}, \mathrm{Cd}, \mathrm{Pb}, \mathrm{Cr}$ and $\mathrm{Mn}$ ( $\mu \mathrm{g} / \mathrm{g}$ of wet weight) in shellfish obtained from Can Gio district in Ho Chi Minh City, Vietnam.

\section{Conclusion}

This study has identified all metals were presented in all samples but values obtained were below permitted limits set by MHV and FDA except $\mathrm{Pb}$ in Scylla serrata. Therefore, the local shellfish from the Can Gio coastline are safe to consume in terms of these selected heavy metal concentrations. However, monitoring of the levels of $\mathrm{As}, \mathrm{Cd}, \mathrm{Pb}, \mathrm{Cr}$ and $\mathrm{Mn}$ in water and shellfish should be carried out routinely so that appropriate prevention of contamination from these toxic metals can be implemented.

\section{ACKNOWLEDGEMENTS}

The authors acknowledged the assistance of staffs from the Laboratory of Physical Chemistry and Analysis, Institute of Chemical Technology, Vietnam Academy Science and Technology throughout the research work.

\section{REFERENCES}

1. T. Alemdaroglu, E. Onur and F. Erkakan, Int. J. Environ. Stud., 60, 287 (2003).

2. Zheng Zhang, Li He, Jin Li and Zhen-bin Wu, Polish J. Environ. Stud., 16, 949 (2007).

3. L.W. Chang, Toxicology of Metals; CRC Lewis Publishers: Boca Raton, FL (1996).

4. J.M. Llobet, G. Falco, C. Casas, A. Teixido and J.L. Domingo, J. Agric. Food Chem., 51, 838 (2002).

5. Ministry of Health of Vietnam, Prescribed Maximum Limit of Chemical and Biological Contamination in Food, Decision 46/2007/QD-BYT 19/12 (2007).

6. US Food and Drug Administration Protecting and Promoting Your Health. Appendix 5-FDA \& EPA Safety Levels in Regulations and Guidance, edn. 3 (2001).

7. J. Burger, K.F. Gaines, C.S. Boring, W.L. Stephens, J. Snodgrass, C. Dixon, M. McMahon, S. Shukla, T. Shukla and M. Gochfeld, Environ. Res., 89, 85 (2002).

8. M. Tuzen, Food Chem., 80, 119 (2003).

9. S.J. Clearwater, A.M. Farag and J.S. Meyer, Compar. Biochem. Physiol. C Toxicol. Pharmacol., 132, 269 (2002).

10. A.T. Law and A. Singh, Marine Pollut. Bull., 22, 86 (1991).

11. B.Y. Kamaruzzaman, N.T. Shuhada, B. Akbar, S. Shahbudin, K.C.A. Jalal, M.C. Ong, S.M. Al-Barwani and J.S. Goddard, Res. J. Environ. Sci., 5, 179 (2011). 
12. M. Alina, A. Azrina, A.S. Mohd Yunus, S. Mohd Zakiuddin, H.M.I. Effendi and R.M. Rizal, Int. Food Res. J., 19, 135 (2012).

13. I. Mat, Bull. Environ. Con. Toxicol., 52, 833 (1994).

14. F. Suhaimi, S.P. Wong, V.L.L. Lee and L.K. Low, Singapore J. Primary Ind., 32, 1 (2005/06).

15. K. Pimonwan, T. Linna and R. Laddawan, J. Health Res., 23, 179 (2009).

16. B.K. Mandal and K.T. Suzuki, Talanta, 58, 201 (2002).

17. Agency for Toxic Substance and Disease Registry (ATSDR), Toxicological Profile for Arsenic. US Department of Health and Humans Services, Public Health Human Services, Centers for Diseases Control, Atlanta (2003).

18. M.P. Waalkes, J. Inorg. Biochem., 79, 241 (2000)

19. E.L.B. Novelli, E.P. Vieira, N.L. Rodrigues and B.O. Ribas, Environ. Res., 79, 102 (1998)

20. H.J.M. Bowen, Environmental Chemistry of the Elementsm, Academic Press, London, p. 269 (1979).
21. L.T. Mui, J. Sci. Technol. Danang Univ., 4, 49 (2008).

22. L. Jarup, Br. Med. Bull., 68, 167 (2003).

23. B.T. Emmerson, Chronic Lead Nephropathy (Editorial) Kidney International, Department of Medicine, Vol. 4, pp. 1-5 (1973).

24. FAO/WHO, List of Maximum Levels Recommended for Contaminants by the Joint FAO/WHO Codex Alimentarius Commission, Second Series, CAC/ FAL, Rome 3, p. 1 (1976).

25. Y. Ishikawa, K. Nakagawa, Y. Satoh, T. Kitagawa, H. Sugano, T. Hirano and E. Tsuchiya, Brit. J. Cancer, 70, 160 (1994).

26. I.J. Eustace, Aust. J. Marine Freshwa. Res., 25, 209 (1974).

27. J.F. Uthe and E.G. Bligh, J. Fisheries Res. Board Canada, 28, 786 (1971).

28. Environmental Fact Sheet ARD-EHP-15, Manganese: Health Information Summary, New Hampshire Department of Environmental Services (2006). 